\title{
Study of the Influence of Chemical Composition on the Pozzolanicity of Soda-lime Glass Microparticles
}

\author{
Rosemary Bom Conselho Sales ${ }^{a *}$, Fernando Augusto Sales ${ }^{b, c, d}$, Elaine Carballo Siqueira Corrêa ${ }^{b, c, d}$, \\ Patrícia Santiago de Oliveira Patricio ${ }^{b, c, d}$, Nelcy Della Santina Mohallem ${ }^{e, f}$,
}

Maria Teresa Paulino Aguilar ${ }^{e, f}$

\begin{abstract}
${ }^{a}$ Departamento de Ciências e Tecnologia, Universidade do Estado de Minas Gerais, Av. Presidente Antônio Carlos, 7545, Pampulha, CEP 31270-010, Belo Horizonte, MG, Brazil ${ }^{b}$ Departamento de Engenharia Mecânica, Centro Federal de Educação Tecnológica de Minas Gerais, Av. Amazonas 5253, Nova Suiça, CEP 30510-000, Belo Horizonte, MG, Brazil

${ }^{c}$ Departamento de Materiais, Centro Federal de Educação Tecnológica de Minas Gerais, Av. Amazonas 5253, Nova Suiça, CEP 30510-000, Belo Horizonte, MG, Brazil

${ }^{d}$ Departamento de Química, Centro Federal de Educação Tecnológica de Minas Gerais, Av. Amazonas 5253, Nova Suiça, CEP 30510-000, Belo Horizonte, MG, Brazil

${ }^{e}$ Departamento de Química, Universidade Federal de Minas Gerais, Av. Presidente Antônio Carlos, 6627, Pampulha, CEP 31270-901, Belo Horizonte, MG, Brazil

${ }^{f}$ Departamento de Engenharia de Materiais e Construção, Universidade Federal de Minas Gerais, Av. Presidente Antônio Carlos, 6627, Pampulha, CEP 31270-901, Belo Horizonte, MG, Brazil
\end{abstract}

Received: November 2, 2014, Revised: September 22, 2015

\begin{abstract}
The use of residues, in partial or total substitution of aggregates or binders in concrete, presents interesting possibilities for obtaining eco-efficient concretes. Research has investigated the use of glass residue in Portland cement composite, whether as an aggregate or a supplementary cementitious material. However, there is still no consensus on the influence of the chemical composition of glass on the behaviour of the composites in which it is used. This paper analyse the influence of this composition on the performance of cement composites produced with microparticles of colourless and amber glass. Pozzolanicity was assessed by direct (Modified Chapelle, electrical conductivity) and indirect test (chemical characterization, X-ray diffraction, thermogravimetric analysis, differential thermal analysis and Strength Activity Index testing. The results show that microparticles of both glass display pozzolanic activity, with no significant differences between them. This confirms the potential for the use of glass microparticles as a supplementary material in cement composites.
\end{abstract}

Keywords: waste glass powder, supplementary cementitious material, pozzolanic activity

\section{Introduction}

The production of Portland cement, a binder used in the fabrication of concrete, has a high impact on the environment and, as such, is associated with elevated environmental costs. In an attempt to minimize this impact, the scientific community has been researching materials that could partially or completely substitute cement ${ }^{1}$. Depending on the granulometry, level of silica and degree of crystallinity, these materials may be used as mineral additions with cementing or pozzolanic action, or as fillers. Pozzolanic additions per se have no binding power, but in the presence of moisture they can chemically react with calcium hydroxide to form a gel of hydrated calcium silicate. The formed gel can reduce porosity of the compound and favour the refinement of grains, thus contributing for greater durability of concrete ${ }^{2,3}$. The occurrence and magnitude of the pozzolanic reaction depends upon the silica content available to react, as well as its thermodynamic stability (amorphicity) and specific surface ${ }^{4-6}$.

*e-mail: rosebcs@gmail.com
The materials most commonly used como pozolanas are fly ash, silica fume and rice husk ash ${ }^{2}$. However, a material currently of interest, both to researchers and to industry, is glass residue. When in the form of shards, the residue is a non-biodegradable inert material with high utilization and recycling rates. It is commonly used as a raw material to manufacture new glasses. In most cases, though, the recycling of glass microparticles derived from plate drilling and cutting does not occur due to logistics and processing characteristics of the glass. Thus, glass wastes in the form of fine powders generate large environmental liability because, when dropped, they reduce the operating life of landfill sites.

Considering that soda-lime glass is a non-crystalline ceramic material, and that more than $95 \%$ of glass is made from silicon dioxide, sodium oxide and calcium, its addition to cement is interesting from a technical point of view. Research into the use of glass residue in cement has evaluated its use as an aggregate ${ }^{7-9}$ or as pozzolanic material ${ }^{10-12}$. However, 
the possibility of an alkali-silica reaction is an aggravating factor for its use $\mathrm{e}^{12,13}$. Nonetheless, recent studies have shown that when incorporated with cement, glass microparticles may reduce the expansion of the alkali-silica reaction in a similar way to slag and fly ash ${ }^{14,15}$. Still, there is no consensus regarding the influence of the chemical composition of glass on the composites produced ${ }^{8,16}$.

\section{Material and Methods}

As a means of minimizing the control variables of the experiments, both colourless and amber glass microparticles were obtained through the milling of soda-lime glass in the laboratory. The cement used was high initial resistance Portland cement (CPV-ARI). The chemical composition of the cement and the glass was assessed with an energy-dispersive spectroscopy (EDS). The glass powder was analysed by X-ray diffraction (XRD) - Rigaku, Geigerflex 3034 - with radiation $\mathrm{CuK} \alpha, 40 \mathrm{kV}$ and $30 \mathrm{~mA}, 0.5 \mathrm{~s}$ time constant, and monochrome graphite crystal. The granulometric distribution of the glass microparticles was obtained by the technique of laser beam scattering in a Cilas 920 granulometer. The thermal analyses (Thermogravimetric Analysis - TGA and Differential Thermal Analysis - DTA) were conducted with samples of $10 \mathrm{mg}$, obtained from pastes made with and without the replacement of cement by $10 \%$ glass. The samples, after being cured for 28 days, were immersed in acetone to interrupt the hydration reaction, and were then milled immediately. The equipment used was a Shimadzu DTG $60 \mathrm{H}$. The reactivity of the glass particles with calcium hydroxide was measured directly in the Modified Chapelle and electrical conductivity test. Chapelle test allows to determine via titration the calcium oxide content fixed in aqueous media by the analyzed material, as established by Raverdy et al. ${ }^{17}$. The test was conducted for each type of glass, and with a control material (silica fume with silica content $>85 \%$ and a surface area between 15 and $35 \mathrm{~m}^{2} / \mathrm{g}$ ). The electrical conductivity test was carried out according to the method proposed by Luxán et al. ${ }^{18}$. This assay has assessed the variation of electrical conductivity of a solution saturated with calcium hydroxide before and after the addition of the pozzolan under controlled conditions. The Strength Activity Index (SAI) was calculated by comparing the compressive strength of mortar (one part binder to three parts sand, and 0.5 of water) with and without the use of $35 \%$ of glass microparticles substituted for cement.

\section{Results}

The chemical analysis of the colourless and amber glass microparticles and the cement is presented in Table 1. Comparing the data with other research in the field, it is clear that the glass microparticles display a very similar composition, typical of soda-lime glass ${ }^{19}$ Comparing the two types of glass, it may be observed that the most representative variations were registered in the aluminium oxides, iron oxides and, most of all, in the levels of sodium oxide. The difference in sodium oxide is reflected directly in the higher value of the alkaline equivalent in colourless glass. According to ASTM C- $618^{20}$, pozzolanic materials should present a maximum alkali level $\left(\mathrm{Na}_{2} \mathrm{O}_{\text {eq }}\right)$ of $1.5 \%$. The microparticles display higher levels than this, which would demand rigorous control of the reactions involving alkalis and the aggregates. The cement used corresponds to the Brazilian specifications for high initial resistance cement. The main phases typically present in these cements are tricalcium silicate, beta-dicalcium silicate, calcium aluminosilicate, aluminates, iron-aluminates and calcium sulphoaluminates.

The granulometric distribution obtained by the laser beam scattering method shows that for colourless glass, $10 \%$ of the particles display a diameter equal to or less than $0.97 \mu \mathrm{m}, 50 \%$ display $4.70 \mu \mathrm{m}$ and $90 \%$ are $22.34 \mu \mathrm{m}$. For the amber glass, $10 \%$ of the particles measure $1.07 \mu \mathrm{m}$, $50 \%$ are $5.65 \mu \mathrm{m}$ and $90 \%$ display a diameter of $28.35 \mu \mathrm{m}$. The average particle size was $8.93 \mu \mathrm{m}$ for colourless glass and $10.61 \mu \mathrm{m}$ for amber glass, respectively. The data indicates that the fineness of the glass is similar, and that the milling was efficient as a method of obtaining microparticles, which would favour the kinetics of pozzolanic reactions.

The colourless and amber glass residues have similar characteristics to the standards of common glass ${ }^{21}$. The diffuse diffractograms observed (Figure 1) are usually attributed to the vitreous phases ${ }^{19}$, indicating that the materials display characteristics of non-crystalline material. Published works on rice husk ash, silica fume, ashes from raw sewage sludge and metakaolin show that the material's reactivity with calcium hydroxide increases with the content of amorphous silica present in the same $\mathrm{e}^{1,7,22-26}$, since its thermodynamic stability is lower. In this way, the obtained results indicate greater reactivity in the glass microparticles. However, there is also evidence suggesting that the granulometry may be just as important as the crystal structure ${ }^{25}$.

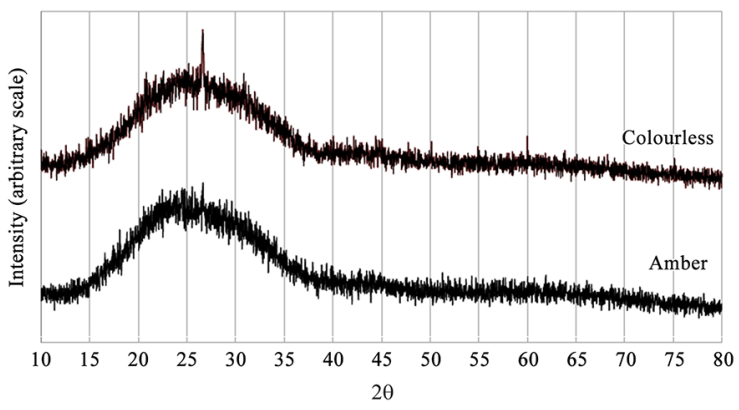

Figure 1. X-ray diffractogram of colourless and amber glass.

Table 1. Chemical composition of glass microparticles and cement.

\begin{tabular}{cccccccccc}
\hline Materials & $\mathbf{R I}$ & $\mathbf{P F}$ & $\mathbf{S i O}_{2}$ & $\mathbf{C a O}$ & $\mathbf{A l}_{2} \mathbf{O}_{3}$ & $\mathbf{F e}_{2} \mathbf{O}_{3}$ & $\mathbf{M g O}$ & $\mathbf{S O}_{3}$ & $\mathbf{N a}_{2} \mathbf{O e q}$ \\
\hline Transparent(\%) & 92.72 & 0.22 & 73.93 & 9.18 & 0.25 & 0.92 & 3.75 & 0.23 & 9.19 \\
Amber(\%) & 94.39 & 0.37 & 72.95 & 9.28 & 0.82 & 0.66 & 3.58 & 0.25 & 6.00 \\
Cement & 1.00 & 3.50 & 24.59 & 56.47 & 7.19 & & 2.43 & 2.60 & \\
\hline
\end{tabular}


The graphs displayed in Figures 2 and 3 illustrate the data obtained from the thermal analysis of the pastes, with and without the replacement of cement by $10 \%$ glass. They show the most significant variations in mass that occurred during the heating of the samples, thus identifying the occurrence and extension of the pozzolanic reaction. The DTA results show the heat involved in the reactions and help to identify the areas where reactions may occur. The areas on the graphs in which variation of the mass occurred in a non-monotonic form, and/or exothermic or endothermic reactions took place, are marked with circles. The hydrated cement (paste) mainly displays the following phases: hydrated tricalcium silicate, hydrated dicalcium silicate, hydrated calcium aluminosilicate, hydrated calcium aluminate, hydrated calcium aluminate trisulphate (ettringite) and calcium hydroxide.

In the existing research, the temperatures at which the dehydration reactions of these phases occur on account of the heat vary, depending on the study. In general, free water or water stored in the capillary structure of the gel is lost between $30-105^{\circ} \mathrm{C}$. By $120^{\circ} \mathrm{C}$, this water has been completely lost. The decomposition of the ettringite occurs between 110$180^{\circ} \mathrm{C}$; the hydrated calcium aluminates and aluminosilicates dehydrate between $180-240^{\circ} \mathrm{C}$; the loss of the combined water of the hydrated calcium silicate occurs between $50-300^{\circ} \mathrm{C}$; the interlayer water of this silicate is lost at $350^{\circ} \mathrm{C}$; the absorbed water of the hydrated calcium silicate exits at around $400^{\circ} \mathrm{C}$; between $410-580^{\circ} \mathrm{C}$ the dehydration of calcium hydroxide is detected; and from $520-900^{\circ} \mathrm{C}$ the calcium carbonate decomposes ${ }^{27-32}$. Zone 2 therefore corresponds to the loss of water in $\mathrm{Ca}(\mathrm{OH})_{2}$. The loss of water, in this area, was less in the paste with amber glass, which indicates that this paste has lower levels of portlandite. Significant quantities of silicates displaying greater loss of mass at temperatures around $200^{\circ} \mathrm{C}$ were not observed.

Table 2 shows the results obtained in the Modified Chapelle test. The average values obtained for the colourless and amber glass - 730.99 and $780.27 \mathrm{mg}$ of $\mathrm{Ca}(\mathrm{OH})_{2} / \mathrm{g}$ respectively - are relatively high for both types of glass. These values are higher than that obtained for silica fume. According to Raverdy et al. ${ }^{17}$, the minimum value for calcium hydroxide consumption required for the material to display pozzolanic activity is $330 \mathrm{mg}$ of $\mathrm{Ca}(\mathrm{OH})_{2} / \mathrm{g}$ sample, or $700 \mathrm{mg} / \mathrm{g}$ according to the Association Française de Normalisation $^{33}$. It may therefore be considered that the microparticles display pozzolanic activity.

Figure 4 shows the results obtained in the electrical conductivity test for the glass microparticles, carried out according to the method proposed by Luxán et al. ${ }^{18}$. The reduction of electrical conductivity of the solution with glass particles may be observed throughout the test, with both types of glass powder. This indicates the reduction of ions in the solution, and the occurrence of a pozzolanic reaction between the glass microparticles and the calcium hydroxide. In addition, the difference between initial conductivity and that measured after two minutes of the test is around $0.4 \mathrm{mS} / \mathrm{cm}$ for both types of glass, which, according to

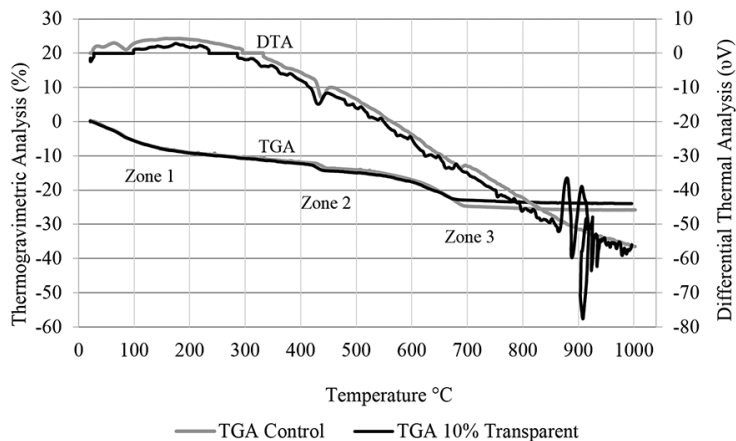

Figure 2. Thermogravimetric and Differential Thermal Analysis with colourless glass.

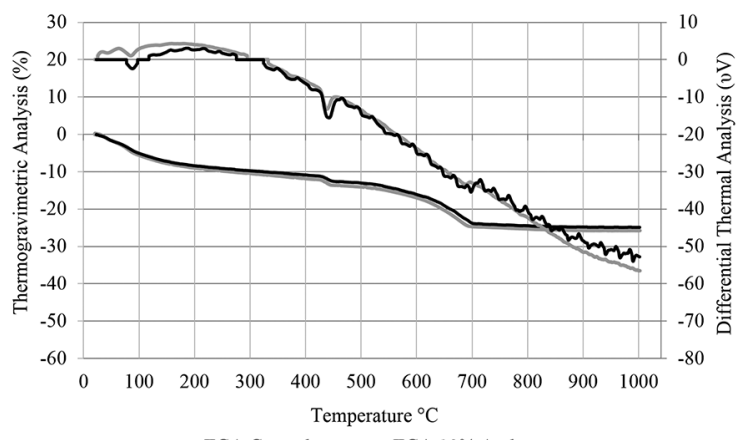

-TGA Control —TGA 10\% Amber

Figure 3. Thermogravimetric and Differential Thermal Analysis test with amber glass.

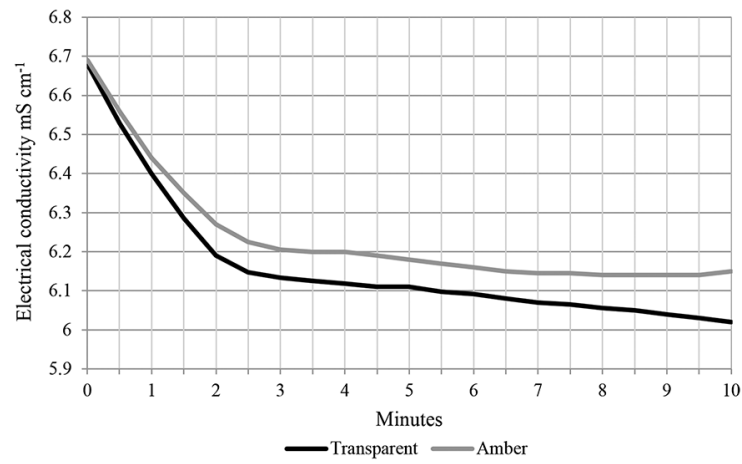

Figure 4. Electrical conductivity test.

Table 2. Modified Chapelle test.

\begin{tabular}{ccccc}
\hline Sample & mg of $\mathbf{C a}(\mathbf{O H})_{2} / \mathbf{g}$ of material & Average \\
\hline Transparent microparticles & 720.85 & 730.56 & 740.20 & 730.99 \\
Amber microparticles & 785.27 & 777.81 & 772.81 & 780.27 \\
Silica fume & 615.45 & - & - & 615.45 \\
\hline
\end{tabular}




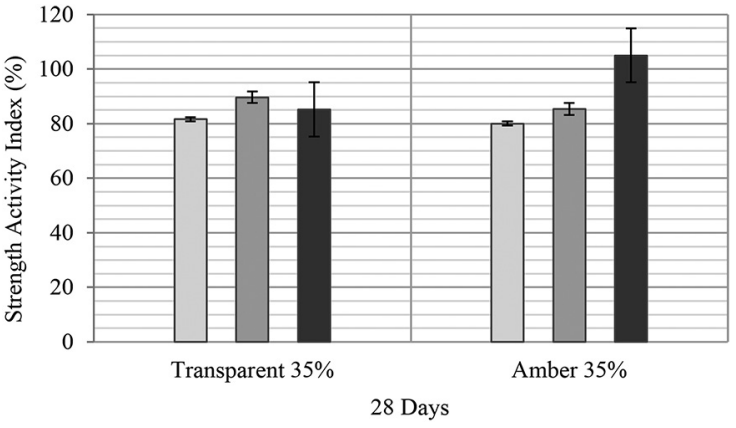

Figure 5. Strength Activity Index test.

those who developed this test, suggests moderate pozzolanic activity for both types of glass.

Figure 5 displays the Strength Activity Index obtained for the cement with and without glass particles. It presents the average values and the range of the data obtained in three test for each of the two samples. According to the Brazilian norm $^{34}$, material is considered pozzolanic if it presents a value equal to or greater than $75 \%$ of the resistance of the reference material after 28 days. The data shows that the glass microparticles, according to the PAI, may be considered pozzolanic, as the value for their activity index with cement is at least $80 \%$. According to the European norm, this material is pozzolanic, as the index is higher than $65 \%{ }^{[35]}$.

\section{References}

1. Sokolovicz BC, Isaia GC and Gastaldini ALG. Concreto com cinza de casca de arroz natural: estudo da penetração de cloretos em protótipos de concreto. In: Anais X Congreso Latinoamericano de Patología Y XII Congreso de Calidad En La Construcción; 2009; Valparaíso, Chile. Valparaíso: CONPAT; 2009. p. 25-34.

2. Mehta PK and Monteiro PJM. Concrete: microstructure, properties, and materials. 4th ed. New York: McGraw-Hill Education; 2014.

3. Donatello S, Tyrer M and Cheeseman CR. Comparison of test methods to assess pozzolanic activity. Cement and Concrete Composites. 2010; 32(2):121-127. http://dx.doi.org/10.1016/j. cemconcomp.2009.10.008.

4. Murat $\mathrm{M}$ and Bachiongini A. Corrélations entre l'état d'amorphisation et l'hydranlicité du métakaolin. Bulletin de Minérologie Bull. Mineralogical Journal. 1982; 105:543-555.

5. Goldman A and Bentur A. Influence of microfillers on enhancement of concrete strength. Cement and Concrete Research. 1993; 23(4):962-972. http://dx.doi.org/10.1016/0008-8846(93)90050-J.

6. Benezet JC and Benhassaine A. The influence of particle size on the pozzolanic reactivity of quartz powder. Powder Technology. 1999; 103(1):26-29.

7. Yuksel C, Ahari R, Ahari B and Ramyar K. Evaluation of three test methods for determining the alkali-silica reactivity of glass aggregate. Cement and Concrete Composites. 2013; 38:57-64. http://dx.doi.org/10.1016/j.cemconcomp.2013.03.002.

8. Idir R, Cyr M and Tagnit-Hamou A. Pozzolanic properties of fine and coarse color-mixed glass cullet. Cement and Concrete Composites. 2011; 33(1):19-29. http://dx.doi.org/10.1016/j. cemconcomp.2010.09.013.

\section{Conclusions}

The microparticles $(\approx 10 \mu \mathrm{m})$ of colourless and amber soda-lime glass display non-crystalline structure and levels of alkalis higher than those recommended for pozzolanic materials. With the Modified Chapelle method, it may be considered that the microparticles display pozzolanic activity. The difference in pozzolanicity between the two types of glass was not significant, taking into account the characteristics of the test. The electrical conductivity test indicated that both types of glass display moderate pozzolanic activity. The TGA showed that only the samples containing amber glass microparticles lost less mass, in the area where the loss of water in portlandite was observed. This indicates a lower quantity of calcium hydroxide in these samples, which in turn suggests the occurrence of a pozzolanic reaction. Significant quantities of silicates that lost greater mass at temperatures around $200^{\circ} \mathrm{C}$ were not observed. The Strength Activity Index results show that while both types of glass microparticles are pozzolanic, it is not possible to assess the influence of type of glass in this index.

\section{Acknowledgements}

This work was supported by Coordination for the Improvement of Higher Education Personnel (CAPES), the Research Support Foundation of the State of Minas Gerais (FAPEMIG), the National Council for Scientific and Technological Development $(\mathrm{CNPq})$ and Brennand Cements.)

9. Miranda EJP Jr, Bezerra HJCL, Politi FS and Paiva AEM. Increasing the compressive Strengh of Portland cement concrete using flat glass powder. Materials Research. 2014; 17(1):45-50. http://dx.doi.org/10.1590/S1516-14392014005000058.

10. Moncea AM, Badanoiu A, Georgescu M and Stoleriu S. Cementitious composites with glass waste from recycling of cathode ray tubes. Materials and Structures. 2013; 46(12):21352144. http://dx.doi.org/10.1617/s11527-013-0041-5.

11. Pereira-de-Oliveira LA, Castro-Gomes JP and Santos PMS. The potential pozzolanic activity of glass and red-clay ceramic waste as cement mortars componentes. Construction \& Building Materials. 2012; 31:197-203. http://dx.doi.org/10.1016/j. conbuildmat.2011.12.110.

12. Antônio AP, Calmon JL and Tristão FA. Resíduo de estação de tratamento de efluentes provenientes da lapidação do vidro plano na produção de concretos. In: $53^{\circ}$ Ibracon - Congresso Brasileiro de Concreto; 2011; Florianópolis, Brasil. Florianópolis: IBRACON; 2011. p. 66-75.

13. Saccani A and Bignozzi MC. ASR expansion behavior of recycled glass fine aggregates in concrete. Cement and Concrete Research. 2010; 40(4):531-536. http://dx.doi.org/10.1016/j. cemconres.2009.09.003.

14. Kawamura M and Fuwa H. Effects of lithium salts on ASR gel composition and expansion of mortars. Cement Concrete Research. 2003; 33(6):913-919.

15. Carpenter AJ and Cramer SM. Mitigation of Alkali-Silica Reaction in pavement patch concrete that incorporates highly reactive fine aggregate. Transportation Research Record: Journal of the Transportation Research Board, 1999; 1968(99-1087): $0-67$ 
16. Khmiri A, Chaabouni M and Samet B. Chemical behaviour of ground waste glass when used as partial cement replacement in mortars. Construction \& Building Materials. 2013; 44:74-80. http://dx.doi.org/10.1016/j.conbuildmat.2013.02.040.

17. Raverdy M, Brivot F, Paillére AM and Dron R. Appreciation de l'actvite pouzzolanique dos constituents secondaires. In: Proceedings of the 7th International Congress on the Chemistry of Cement; 1980; Paris, França; Paris: Editions Septima; 1980; v. 3. p. 36-41.

18. Luxán MP, Madruga $F$ and Saavedra J. Rapid evaluation of pozzolanic activity of natural products by conductivity measurement. Cement and Concrete Research. 1989; 19(1):6368. http://dx.doi.org/10.1016/0008-8846(89)90066-5.

19. Smith WF. Principios de ciência e engenharia dos materiais. 3rd. ed. Lisboa: McGraw-Hill; 1998.

20. American Society for Testing and Materials - ASTM. ASTM C618: Specifications for fly ash and raw or calcined natural pozzolan for use as a mineral admixture in Portland cement. West Conshohocken: ASTM; 1989.

21. Shi $\mathrm{C}$ and Zheng $\mathrm{K}$. A review on the use of waste glasses in the production of cement and concrete. Resources, Conservation and Recycling. 2007; 52(2):234-247. http://dx.doi.org/10.1016/j. resconrec.2007.01.013.

22. Wansom S, Janjaturaphan S, Sinthupinyo S. Pozzolanic activity of rice husk ash: comparison of various electrical methods. Journal of Metals, Materials and Minerals. 2009; 19(2):1-7.

23. Mostafa NY, El-Hemaly SAS, Al-Wakeel EI, El-Korashy SA and Brown PW. Characterization and evaluation of the pozzolanic activity of Egyptian industrial by-products I: silica fume and dealuminated kaolin. Cement and Concrete Research. 2001; 31(3):467-474. http://dx.doi.org/10.1016/S0008-8846(00)00485-3.

24. He C, Osbaeck B and Makovicky E. Pozzolanic reactions of six principal clay minerals: activation, reactivuty assessments and technological effects'. Cement and Concrete Research. 1995; 25(8):1691-1702. http://dx.doi.org/10.1016/00088846(95)00165-4.

25. Baeza-Brotonsa F, Garcésa P, Payáb J and Savala JM. Portland cement systems with addition of sewage sludge ash. Application in concretes for the manufacture of blocks. Journal of Cleaner Production, 2014; 82:112-124.
26. Tantawy MA, El-Roudi AM, Abdalla EM and Abdelzaher MA. Evaluation of the Pozzolanic activity of sewage sludge ash. Chemical Engineering Journal, 2012; 2012:487037.

27. Scrivener KL and Nonat A. Hydration of cementitious materials, present and future. Cement and Concrete Research. 2011; 41(7):651-665. http://dx.doi.org/10.1016/j.cemconres.2011.03.026.

28. Alarcon-Ruiz L, Platret G, Massieu E and Ehrlacher A. The use of thermal analysis in assessing the effect of temperature on a cement paste. Cement and Concrete Research . 2005; 35(3):609613. http://dx.doi.org/10.1016/j.cemconres.2004.06.015.

29. Dweck J, Buchler PM, Coelho AV and Cartledge F. Hydration of a Portland cement blended with calcium carbonate. Thermochimica Acta. 2000; 346(1-2):105-113. http://dx.doi. org/10.1016/S0040-6031(99)00369-X.

30. Knopf FC, Roy A, Samrow HA and Dooley KM. High-pressure molding and carbonation of cementitious materials. Industrial \& Engineering Chemistry Research. 1999; 38(7):2641-2649. http://dx.doi.org/10.1021/ie980705y.

31. Paya J, Monzó J, Borrachero MW and Velázquez S. Evaluation of the pozzolanic activity of fuid catalytic cracking residue (FC3R), Thermogravimetric analysis studies on FC3R-Portland cement pastes. Cement and Concrete Research. 2003; 33(4):603-609. http://dx.doi.org/10.1016/S0008-8846(02)01026-8.

32. Rodrigues MS, Monzó JM, Borrachero V, Payá J, Beraldo AL and Savastano H Jr. Characterization and pozzolanic evaluation of sugar cane bagasse ashes. In: International Conference on Non-Conventional Materials and Technologies; 2010; Cairo, Egypt. Cairo: IC-NOCMAT; 2010. p. 1-9.

33. Association Française de Normalisation - AFNOR. NFP 18513: 2012: Métakaolin, addition pouzzolanique pour bétons: définitions, spécifications, critères de conformité. La Plaine Saint-Denis: AFNOR; 2012.

34. Associação Brasileira de Normas Técnicas-ABNT. ABNTNBR 12653: 2012: Materiais pozolânicos. Rio de Janeiro: ABNT; 2012.

35. Instituto Português da Qualidade-IPQ. NP EN 4220: Pozolanas para betão, argamassa e caldas. Definições, requisitos e verificação da conformidade. Lisboa: IPQ; 2010. 